\section{Recovery of human foetal liver cells after storage in liquid nitrogen}

A. J. ZUCKERMAN, H. E. M. KAY, AND A. B. HOCKLEY From the London School of Hygiene and Tropical Medicine and the Royal Marsden Hospital, London

It has now been firmly established that the storage of tissue culture cells in liquid nitrogen at a temperature range of $-150^{\circ} \mathrm{C}$. to $-195^{\circ} \mathrm{C}$. largely prevents deterioration due to thermodynamic changes (Nagington and Lawrence, 1962). Recently a method of culturing fully differentiated human embryo hepatocytes was developed (Zuckerman, Tsiquaye, and Fulton, 1967). We now describe the methods for the preparation of the liver for preservation in liquid nitrogen and for the recovery of the liver cells after thawing.

Livers were obtained by the tissue bank of the Royal Marsden Hospital, after abdominal hysterotomy, from human embryos in whom there was no suspicion of infection in the mother or the foetus. The age of the embryos varied from 8 to 20 weeks. The livers were placed in medium 199 and transferred to the laboratory on melting ice. Disaggregation of the liver cells was carried out by gentle trypsinization with $0.25 \%$ trypsin at room temperature. After inactivation of the trypsin by the addition of calf serum to give a final concentration of $20 \%$ serum in the cell suspension, the cells were centrifuged at 500 r.p.m. at $4^{\circ} \mathrm{C}$. for five minutes. The packed cells were washed once in the growth medium made up with Eagle's minimum essential medium, $10 \%$ foetal calf serum, $0 \cdot 15 \%$ sodium bicarbonate, 100 units $/ \mathrm{ml}$. penicillin, and $100 \mu \mathrm{g} . / \mathrm{ml}$. streptomycin. The cells were resuspended in the growth medium and transferred to the tissue bank on melting ice for storage in liquid nitrogen.

At the tissue bank the suspensions were centrifuged at 500 r.p.m. at $4^{\circ} \mathrm{C}$. for five minutes. Half of the suspending

Received for publication 24 May 1967.

A fluorescent technique for demonstrating treponemes in films made from suspected chancres-concluded

as does the dark-ground method, the presence of treponemes morphologically indistinguishable from Treponema pallidum. The final diagnosis of syphilis rests, as it does in the dark-ground examination, on a combination of history, a sore, and the presence of treponemes.

This paper is published with the approval of the Director-General of Public Health, New South Wales.

\section{REFERENCES}

Fry, C. S., and Wilkinson, A. E. (1963). Brit. J. vener. Dis., 39, 190. Wilkinson, A. E., and Rayner, C. F. A. (1966). Ibid., 42, 8. medium was removed and replaced with cold medium 199 containing $20 \% \mathrm{~V} / \mathrm{V}$ dimethyl sulphoxide, to give a final concentration of $10 \%$ sulphoxide. The cell suspension was transferred in aliquots of 2.0 to $2.5 \mathrm{ml}$. to polyethylene ampoules, which were then heat-sealed and cooled at controlled rates. The apparatus used is similar to that previously described (Pegg, 1966) and depends upon cold alcohol $\left(-79^{\circ} \mathrm{C}\right.$.) being mixed in controlled quantities with the alcohol in which the ampoules are immersed. The programme of cooling is set by a rotating cam and the quantity of injected cold alcohol is determined from moment to moment by a comparison of the actual temperature of the ampoules with the temperature set by the cam.

The rate of cooling was $1^{\circ} \mathrm{C}$. per minute from $5^{\circ} \mathrm{C}$. to $-15^{\circ} \mathrm{C}$., and $5^{\circ} \mathrm{C}$. per minute between $-15^{\circ} \mathrm{C}$. and $-50^{\circ} \mathrm{C}$. The ampoules were transferred to a liquid nitrogen container and stored in nitrogen vapour $\left(-160^{\circ} \mathrm{C}\right.$.) for periods varying between two and seven weeks. When required, the ampoules were removed from the container and placed in a water bath at $40^{\circ} \mathrm{C}$. Gentle agitation ensured complete, rapid thawing in two to three minutes. As soon as the last piece of solid 'ice' had disappeared the ampoules were placed on melting ice and sent to the tissue culture laboratory.

The ampoules were opened on arrival, and the suspen-

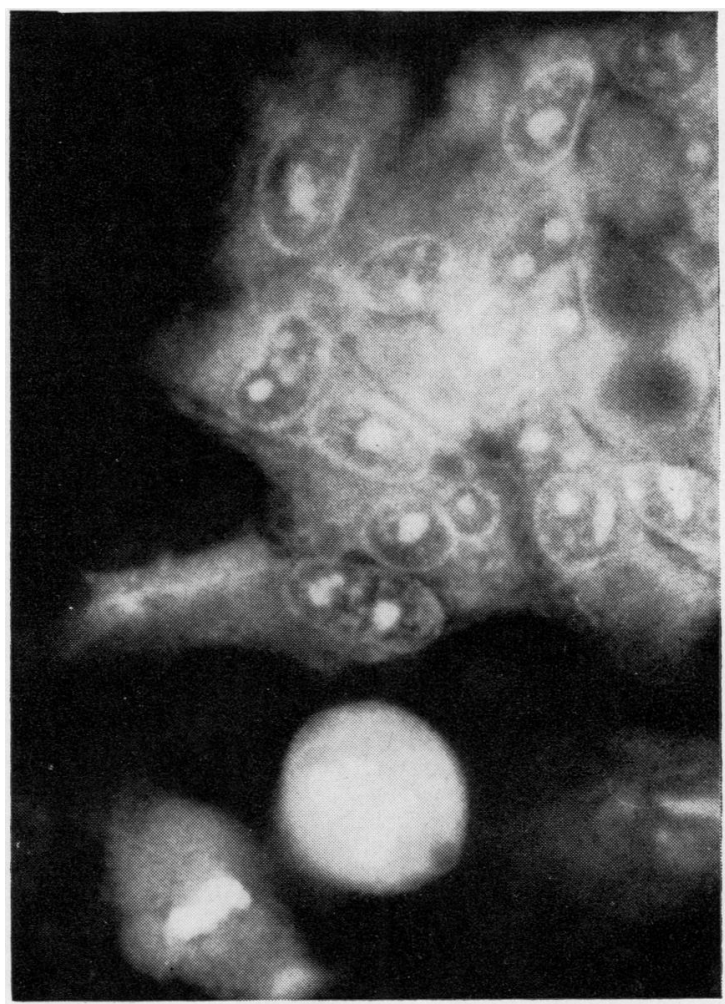

FIG. 1. Human foetal liver cells after recovery from storage in liquid nitrogen. Two mitotic figures are present on the lower margin of the culture. 48 hours in culture. $\times 900$. 


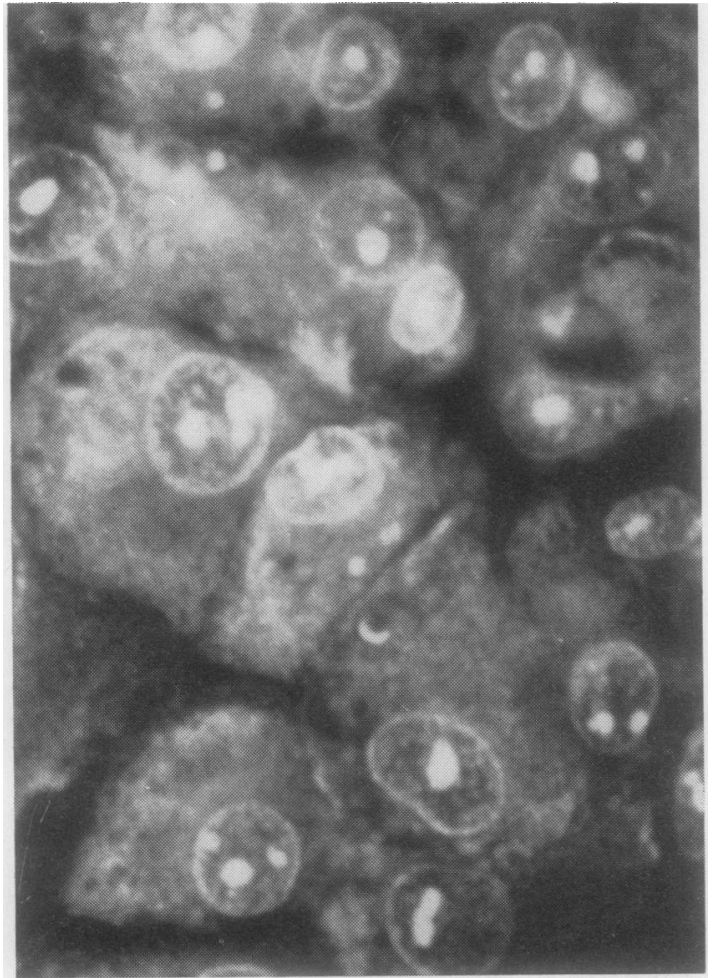

FIG. 2. Foetal hepatocytes after four days in culture. $\times 900$.

sions centrifuged at 500 r.p.m. for five minutes at $4{ }^{\circ} \mathrm{C}$. The packed cells were washed once in the growth medium and centrifuged again before resuspending them in a minimal amount of the growth medium. The liver cells were subsequently cultured after implantation by the method of Zuckerman, Tsiquaye, and Fulton (1967).

The cultures were examined by phase-contrast illumination and by fluorescence microscopy after staining with acridine orange. A practically confluent viable monolayer of cells was obtained after 24 hours in culture, and after 48 hours a number of mitoses were observed in the preparations (Fig. 1). Cell debris was present in small quantities, particularly at the periphery of the culture and after four days the cells were healthy and viable (Fig. 2).

By this technique it is regularly possible to obtain at least 32 separation cultures from the cell suspension contained in a single ampoule.

It is a pleasure to thank members of the Tissue Bank of the Royal Marsden Hospital. Miss Susan Baker, B.Sc., and Miss Lorna Dunkley provided excellent technical assistance.

\section{REFERENCES}

Nagington, J., and Lawrence, M. F. (1962). Mth. Bull. Minist. Hith. Lab. Serv., $21,162$.

Pegg, D. E. (1966). Bone Marrow Transplantation. P. 178. Lloyd-Luke, London.

Zuckerman, A. J., Tsiquaye, K. N., and Fulton, F. (1967). Brit. J. exp. Path., 48, 20.
Rapid method for the estimation of plasma haemoglobin levels

C. M. CRIPPS From the Department of Pathology $\frac{\bar{\Phi}}{\overparen{\Phi}}$

St. Bartholomew's Hospital, London के

The increasing use of extracorporeal circulation in cardiac surgery has led to a renewed interest in the levels of plasma haemoglobin in view of the possible dangers tor patients. During the course of recent studies with differentr. pumps and oxygenators a need was felt for a reasonably accurate and simple method for this estimation. spectrophotometric method of analysis seemed to offer the best solution to the requirements.

The simple measurement of the optical density of specimen at a characteristic absorption band for oxyhaem oglobin does not give satisfactory results because of thepresence of bilirubin and small quantities of other pigণ్ ments. However, when optical density measurement? need to be made in the presence of a background level ô other absorbing materials it is possible to correct for the non-specific light absorption in a manner which has beeno described by Allen (1950) for ketosteroids and b.8 Rimington and Sveinsson (1950) for porphyrins.

An inspection of the absorption curve of oxyhaemoo globin suggested that the same principle could be used fo its estimation in plasma and this has been applied in thछ method described.

\section{MATERIALS}

INSTRUMENT The Unicam S.P. 600 spectrophotometer with $1 \mathrm{~cm}$. cells was used throughout and special care was taken to check the wavelength calibration by means of Didymium glass filter.

STANDARDS A stock solution of oxyhaemoglobin was. made by haemolysing the red cells of pooled heparinized blood with distilled water, the solution then being clarifieđ by centrifugation. Suitable dilutions of this solution were made in phosphate buffer $(p \mathbf{H} 7 \cdot 5)$ to obtain final concen? trations of oxyhaemoglobin to cover the range 5-75 $\mathrm{mg}$ per $100 \mathrm{ml}$. The haemoglobin content was found b⿸广 making parallel dilutions in a modified Drabkin's solus tion (Dacie and Lewis, 1963a), and the cyanmethaemoglobin concentration of each dilution was found bf reference to a known cyanmethaemoglobin standarÆ్E solution (B.D.H.).

BLOOD SAMPLES Samples were obtained either by cleaf venepuncture with a wide-bore needle, or, in the theatres directly into the syringe from the oxygenator. The speci mens were transferred to heparinized plastic centrifugg tubes and centrifuged at 1,500 r.p.m. for five minute The plasma was removed and centrifuged a second time to remove all cells.

Received for publication 25 May 1967. 